\title{
BMI and Serum Lipids
}

Sir,

I read the recent publication by Azita et al on BMI and serum lipid with a great interest. Azita et al mentioned that "it is necessary to measure serum lipid profile in obese and overweight children. ${ }^{1 "}$ Indeed, the problem of lipidemia in pediatrics is a new concern. Correlation between serum lipid and BMI is studied in some previous works. In a Chinese study, the relationship between serum lipid and BMI could not be identified although the obesity and overweight among the studied children could also be observed..$^{2-3}$ Similar null correlation was also reported from a Japanese study. ${ }^{4}$ Due to the changing world, the obesity and overweight have become the new problem in pediatrics. However, the relationship between $\mathrm{BMI}$ and serum lipid needs further study for clarification.

\section{REFERENCES}

1. Azita F, Asghar Z, Gholam-Reza S. Relationship of body mass index with serum lipids in elementary school students. Indian I Pediatr 2009; 76: 729-731.

2. Hu P, Qin YH, Jing CX, Lu L, Hu B, Du PF. Effect of apolipoprotein $\mathrm{B}$ polymorphism on body mass index, serum protein and lipid profiles in children of Guangxi, China. Ann Hum Biol 2009; 36: 411-420.

3. Liao Y, Liu Y, Mi J, Tang C, Du J. Risk factors for dyslipidemia in Chinese children. Acta Pediatr 2008; 97: 1449-1453.

4. Kaneshi T, Yoshida T, Ohshiro T, Nagasaki H, Asato Y, Ohta T. Birthweight and risk factors for cardiovascular diseases in Japanese schoolchildren. Pediatr Int 2007;49: 138-143.

\section{Author's Reply}

Sir,

Childhood obesity is increasing in the world and is associated with cardiovascular risk factors like hypertension and dyslipidemia. In studies in Venezuela ${ }^{1}$ and Taiwan ${ }^{2}$ the incidence of dyslipidemia in obese children was significantly higher than children with normal weight. Due to increasing rate of obesity in children in recent years in the world, I think it is very important to find the risk factors of it. I recommend doing more studies about the relationship between obesity and dyslipidemia in children in different countries because difference in different studies may be related to race.

Fesharakinia Azita Assistant Professor of Pediatric Nephrology, Vali-e-asr Hospital, Birjand University of Medical Sciences, Birjand, Iran E-mail: fesharakinia@yahoo.com

\section{REFERENCES}

1. Paoli M, Uzcatequil L. Obesity in schoolchildren from Merida, Venezuela, association with cardiovascular risk factors. Endocrinol Nutr 2009; 56 : 218-226.

2. Chu NF, Rimm EB, Wang DJ. Clustering of cardiovascular disease risk factors among obese schoolchildren; the Taipei children heart study. AM J Clin Nutr 1998; 67: 1141-1160. 